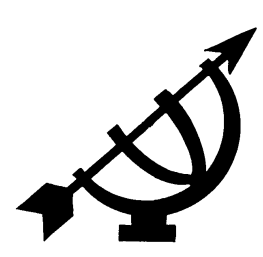

\title{
Godsdiens as 'n moontlike faktor in onderwysstelsels en die beplanning daarvan
}

\author{
J.L. van der Walt \& C.C. Wolhuter \\ Fakulteit Opvoedingswetenskappe \\ Potchefstroomkampus \\ Noordwes-Universiteit \\ POTCHEFSTROOM \\ E-pos: jlvdwalt@intekom.co.za \\ sooccw@puk.ac.za
}

\begin{abstract}
Religion as a possible factor in education systems and their planning
\end{abstract}

Students of education systems distinguish a number of factors that can impact on education systems and their planning. Religion, however, is rarely if ever mentioned as a factor in education system planning. In this article, the authors reflect on various facets of the question as to why religion has not been acknowledged as a factor in education systems in modern societies. The following aspects of the problem are addressed: the nature of the education system; the influence of secularism on education systems and their planning; problems which would be encountered if religion were to be taken into account in education system planning; and the accommodation of religions and religious diversity in education systems.

The conclusion is drawn that in the contemporary world, religion is recognised as a factor in education system planning only in the form of secularism (with a few exceptions, such as in mono-religious Islamic states). All other religions are relegated from public life to the private spheres of people's lives. Because secularism embodies the notion of a public morality that can potentially be shared by (and should be promoted among) all citizens of a particular country or society, secular values tend to be incorporated in the constitutions and other laws of countries. As a result, this value system tends to be promoted by means of the public education system. The article ends with two scenarios of what can be expected to happen if the opposite were allowed to happen, and schools, for instance, were not expected 
to adhere to secular values, but rather to the "sectarian" religious values of their choice.

\section{Opsomming}

\section{Godsdiens as 'n moontlike faktor in onderwysstelsels en die beplanning daarvan}

In die onderwysstelselkunde word 'n hele reeks faktore onderskei wat 'n invloed op die onderwysstelsel kan hê. Godsdiens word egter selde of ooit in die hedendaagse opset van onderwysstelselbeplanning as sodanige faktor genoem of behandel. Dié artikel bied 'n besinning oor verskillende fasette van die vraag waarom godsdiens in hedendaagse regstaatsamelewings nie as 'n faktor in onderwysstelsels erken skyn te word nie. Aandag word aan die volgende aspekte van die probleem gegee: die wese van die onderwysstelsel; die invloed van die sekularisme op onderwysstelsels en hulle beplanning; probleme wat ondervind kan word indien godsdiens as 'n faktor in onderwysstelselbeplanning beskou word, en die akkommodering van godsdiens en godsdiensverskeidenheid in die onderwysstelsel.

Die gevolgtrekking word gemaak dat godsdiens in die hedendaagse wêreld net in die vorm van sekularisme erken word as 'n faktor wat in ag geneem moet word met onderwysstelselbeplanning (met enkele uitsonderings, soos in enkelgodsdiens Moslemlande). Alle ander godsdienste word weens die sekularisme uit die openbare lewe verdring na mense se privaatlewens. Omdat die sekularisme die gedagte beliggaam dat daar 'n openbare moraliteit en universeel geldende waardes is wat alle burgers in 'n bepaalde land of samelewing met mekaar kan deel, word hierdie waardes gewoonlik opgeneem in die grondwette van lande en in ander wetgewing. Juis hierdie waardestelsel word dan deur die openbare onderwys bevorder. Die artikel sluit af met twee scenario's van wat verwag kan word indien die teenoorgestelde toegelaat word om te gebeur - indien skole byvoorbeeld toegelaat word om nie sekularistiese waardes aan te hang nie, maar wel die waardes van die "sektariese" godsdiens van hulle keuse.

\section{Inleiding en probleemstelling}

In die onderwysstelselkunde word 'n hele reeks faktore onderskei wat 'n invloed op die onderwysstelsel kan hê (vgl. Van Schalkwyk, 1995:32-41; Wolhuter et al., 2003:30). So word getalle byvoorbeeld as 'n faktor gebruik wanneer keuses gemaak moet word in verband met die aantal skole wat benodig word om te voorsien in die behoeftes van die aantal leerders in die land, die aantal leerders wat in 'n skool gehuisves kan word, asook die aantal leerders per opvoeder (vgl. Maarman et al., 2006). Taal is 'n faktor in besluite wat 
geneem moet word oor die medium van onderrig (enkel, dubbel- of parallelmedium) (vgl. Murray, 2002). Die estetiese as 'n faktor beïnvloed byvoorbeeld besluite oor hoe die skool argitektonies daar moet uitsien, of hoedanig die skooldrag van die leerders moet wees (vgl. Department of Education and Science and the Welsh Office, 1989:13). Die ekonomiese as faktor kan regstreeks in verband gebring word met die bekostigbaarheid van die onderwys (subsidies, die skoolgeld wat gehef word, vrystelling van betaling daarvan). Die historiese as faktor hou weer verband met kulturele aspekte, in die sin dat die skool moet pas by die kultuurhistoriese omstandighede van die omliggende gemeenskap. Die fisiese as faktor word in ag geneem by die bepaling van hoe groot die skoolterrein moet wees, en hoe ver die leerders moet reis na die skool toe.

Bogenoemde is slegs enkele voorbeelde van die talle faktore wat die onderwysstelsel beïnvloed. Wat egter opval wanneer werke oor die onderwysstelselkunde geraadpleeg word, is dat godsdiens selde, indien ooit, in die hedendaagse onderwysstelselbeplanning pertinent as 'n faktor in of van die onderwysstelsel genoem of behandel word. Gewoonlik kom godsdiens net ter sprake in een van vyf ander verbande met die onderwys:

- In die geskiedenis van die onderwys en van skoolstigting speel die godsdiens van die oprigters dikwels 'n rol. Bekende voorbeelde hiervan vind ' $n$ mens in die klooster- en katedraalskole van die Middeleeue in Europa, in die Suid-Afrikaanse onderwysgeskiedenis, veral dié van die blankes kort na die nedersetting in 1652, en in die eerste skole wat in die VSA opgerig is. In hierdie voorbeelde speel godsdiens slegs 'n histories-agterhaalde rol in die bepaling van die aard en karakter van die skole.

- In die vroegste geskiedenis van die meeste onderwysstelsels is daar sprake van kerkskole. In sulke gevalle is die godsdiens in die skool gereduseer tot die kerklike of institusionele aspek van die beoefening daarvan. In sulke gevalle is daar ook 'n opvallende miskenning van die beginsel van soewereiniteit in eie kring. Die selfstandigheid van die skool word aangetas, aangesien dit onder die toesig van 'n ander lewensverband, die kerk, gestel word. 'n Variasie hiervan is ouer-onderwyserkerkskole.

- In meer resente tye speel godsdiens veral 'n bepalende rol by die oprigting van onafhanklike (ook bekend as privaat-) skole. In die meeste lande word sulke skole opgerig en in stand gehou deur die Rooms-Katolieke Kerk, maar in baie lande is daar ook 
soortgelyke Protestantse skole. Ander bekende voorbeelde van hierdie tipe skole is die Madrassa-skole van die Moslemgemeenskap, en die sinagogeskole van die Joodse gemeenskap. Hoewel daar vir die oprigting, finansiering, bestuur, eksaminering en dies meer van hierdie skole voorsiening gemaak word in die betrokke lande se wetgewing, staan hulle meestal eintlik buite die openbare skoolstelsel, en word aanvaar dat hulle taamlik outonoom en selfstandig funksioneer.

- In sommige gevalle word godsdiensgestempelde skole opgerig uit protes teen die gees en rigting van die openbare onderwys. 'n Bekende voorbeeld hiervan is die Christian Day School Movement in Noord-Amerika (vgl. Van Brummelen, 1989).

- Godsdiens word dikwels ook in verband gebring met die onderwys(stelsel) in die keuses wat gemaak moet word rondom die aanbieding van 'n skoolvak soos Bybelkunde en 'n vormende vak soos Bybelonderrig, asook ruimte vir godsdienstige plegtighede. In hierdie geval kan 'n mens egter nie aanvoer dat godsdiens 'n "faktor" in die onderwysstelsel is nie. 'n Mens kan hoogstens sê dat daar besin word oor hóé die onderwysstelsel godsdiens, of 'n verskeidenheid godsdienste, (kan) akkommodeer.

'n Ontleding van werke op die vakgebiede van die vergelykende opvoedkunde en die onderwysstelselkunde toon dat godsdiens as sodanig tans selde of nooit pertinent as 'n faktor in of van 'n hedendaagse onderwysstelsel in ag geneem word. Anders gestel: onderwyskundiges wat 'n onderwysstelsel bedink, laat hulle selde lei deur die beginsels wat voortvloei uit die dogma of teologie van een van die hoofstroomgodsdienste in 'n land, as hulle die stelsel beplan en bou.

Daar is egter noemenswaardige uitsonderings op hierdie reël. Die Nederlandse onderwysstelsel sedert 1917, waarin die verskillende godsdienste 1 elkeen in 'n "suil" verskans is, is so 'n uitsondering een wat indertyd as merkwaardig en inderdaad as 'n uitsondering beskou is (vgl. Van den Berg, 1992; Sturm et al., 1998). Intussen is die "versuiling" egter aan die verwater ten gunste van groter inklusiwiteit (Weigand-Timmer, 2005). In Midde-Oosterse lande soos Iran, Saoedi-Arabië, Brunei, Pakistan, Bangladesh en Egipte, waar

$1 \quad$ Kerklike denominasies word hierby ingesluit. Tot ongeveer die sestigerjare is die inrigting van 'n skool in baie gevalle bepaal deur die leerstellige uitgangspunte van die kerklike denominasie, saamgevoeg in 'n bepaalde "suil". 
die hele gemeenskap monolities enkelgodsdienstig Moslem is, is godsdiens waarskynlik die belangrikste determinant vir die struktuur en die inrigting van die onderwysstelsel (vgl. Talbani, 1996).

Bogenoemde is egter ' $n$ paar duidelike uitsonderinge op die reel. ${ }^{2}$ In feitlik alle moderne, ontwikkelde gemeenskappe, veral gemeenskappe wat hulself as regstate sien en waar fundamentele menseregte erken word, word godsdiens nie as 'n faktor in die struktuur, die aard of die inrigting van die onderwysstelsel beskou nie. Dit is waarskynlik die vernaamste rede waarom "versuiling", waarvoor gereformeerde (dit wil sê reformatories - nie Gereformeerd in kerklike sin nie) Christene in Nederland vir ongeveer twee eeue gestry het, deesdae aan die verdwyn is. Die Nederlandse samelewing het sedert die Tweede Wêreldoorlog so multikultureel en multigodsdienstig geraak dat versuiling nie meer haalbaar skyn te wees nie. Inklusiwiteit skyn deesdae die belangrikste oorweging te wees by die beplanning van die struktuur en die inrigting van die onderwysstelsel en van skole (Bakker, 2004:5, 7, 16 e.v.; Weigand-Timmer, 2005:1; Tervoort, 2005:146; Strietman, 2005:19).

In die besinning wat hierna volg, word aandag gegee aan verskillende fasette van die vraag waarom godsdiens in moderne, ontwikkelde regstaatgemeenskappe blykbaar nie as 'n faktor in en van die onderwysstelselbeplanning erken word nie. Aandag sal in die proses aan die volgende aspekte van die probleem gegee word:

- Die wese van die onderwysstelsel.

- Die invloed van die sekularisme in onderwysstelsels en hulle beplanning.

- Die akkommodering van godsdienste en godsdiensverskeidenheid in die onderwysstelsel.

2 Daar is ook enkele ander, minder bekende, uitsonderings. Een hiervan is die stelsel in Newfoundland, Kanada, waarvan die hele openbare onderwysstelsel deur 'n raad van 27 kerke en denominasies beheer word (Arends et al., 1998:288). In Bhutan vorm Boeddhistiese kloosterskole nog 'n groot komponent van die openbare skoolstelsel (Crellin, 1995:105). In China kan baie van die elemente van die openbare staatsideologie, soos dit in die skole toegepas word, teruggespoor word na die Confucianisme as godsdiens (Lemmer, 1995:291). In Belize is onderwysvoorsiening gebaseer op 'n vennootskap tussen die staat en die kerk, met sterk kerklike inspraak en deelname aan die formulering van die onderwysbeleid, eienaarskap van openbare skole en die aanstelling of ontslag van onderwysers (Bennett, 1995:93). 
- Probleme wat moontlik ondervind kan word indien godsdiens as 'n faktor in onderwysstelsels en hulle beplanning beskou sou word.

Hierdie besinning word aan die hand van 'n literatuurstudie gedoen. Nadat die probleem van godsdiens as 'n moontlike faktor by onderwysstelselbeplanning van verskillende kante bekyk en oorweeg is, word tot 'n gevolgtrekking gekom.

\section{Die wese van die onderwysstelsel}

Steyn et al. (2002:54 e.v.) kom tot die gevolgtrekking dat dit uiters moeilik is om die verskynsel onderwysstelsel afdoende te definieer of te omskryf, juis omdat die definisies of omskrywings afhang van die vooronderstellings van die betrokke onderwysstelselkundiges. Vele skrywers oor onderwysstelsels (bv. Van Schalkwyk, 1995; Bondesio \& Berkhout, 1987; vgl. ook die omvattende beskrywing in Van Schalkwyk, 1981) verskaf geen definisie van die begrip onderwysstelsel nie, maar probeer die onderwysstelsel as verskynsel toelig deur verduidelikings te gee oor wat dit alles behels en wat die kenmerke daarvan is. Steyn et al. (2002:53-57) kom tot die gevolgtrekking dat daar tog 'n aantal gemeenskaplikhede is in die verskillende definisies en omskrywings. Hulle beklemtoon dat dit die omvattendste kultuurproduk is van die mens op die terrein van die onderwys (vgl. ook Steyn et al., 2003:5), en dat dit 'n sosiale vervlegtingstruktuur is

waarin sosiale strukture van 'n bepaalde samelewing met die onderwysinrigtings verenig om deur koördinasie van bydraes en deur organisasie die versnelde ontsluiting van die jeug binne ' $n$ bepaalde staatsgebied te weeg te bring in aansluiting by die natuurlike eise van tyd en plek (vgl. ook Van Schalkwyk, 1981:79142; Vos \& Barnard, 1984:37).

Steyn et al. (2002:53-57) noem verder dat die definisies en omskrywings die onderwysstelsel beskryf as ' $n$ instrument wat deur 'n gemeenskap geskep word om onderwys aan sy lede op 'n doelgerigte, beplande en geordende wyse te voorsien; dit is die hooftaak van die onderwysstelsel om opvoedende onderwys te voorsien (vgl. ook Bondesio \& Berkhout, 1987:36). Steyn et al. (2002:56) sluit hulle bespreking van die onderwysstelsel af deur te wys op kernbegrippe wat met onderwysstelsels geassosieer word: logistieke struktuur, effektiewe onderwys, onderwysbehoeftes waarin voorsien moet word, 'n groep mense wat gemeenskaplike behoeftes het, en die staatsterritorium ('n kriterium wat hulle bevraagteken, aangesien dit beperkend inwerk op die stelsel). 
Soortgelyke stelle kernbegrippe kom voor in die beskrywings van ander skrywers soos Stone (1981), Van Schalkwyk (1981), en Bondesio en Berkhout (1987:34-44).

In Steyn et al. (2002:53-57) se ontleding van die beskouings van die onderwysstelsels word allerlei indikatore, faktore en kernbegrippe rakende die ontstaan en struktuur van stelsels genoem, soos doelstellings, administrasie, finansiering, organisasie, kurrikula en onderwysersopleiding (vgl. ook Stone, 1981:45-88; Van Schalkwyk, 1995:9, 33, 34-43). Hulle lê ook nadruk daarop dat opvoedende onderwys as die hooftaak van onderwysstelsels beskou kan word, om sodoende in die onderwysbehoeftes van die gemeenskap te voorsien. Godsdiens word egter nie as 'n indikator, faktor of kernbegrip genoem nie.

Hierdie oorsig van sienings oor wat 'n onderwysstelsel in wese is, bring verskeie vrae na vore wat met die tema van hierdie besinning verband hou:

- Sou 'n mens nie die verskynsel onderwysstelsel anders definieer indien daar aanvaar word dat godsdiens ook 'n faktor is wat nie oor die hoof gesien kan of behoort te word nie?

- As die onderwysstelsel die "omvattendste kultuurproduk van die mens op die terrein van die onderwys is", moet dit dan nie ook die mens se godsdiens en sy godsdienstige aard insluit en daarvoor voorsiening maak nie?

- As die stelsel die koördinasie van bydraes deur sosiale strukture in die samelewing is om die ontsluiting van die jeug teweeg te bring, speel godsdienstige strukture dan nie ook 'n rol hierin nie?

- As die "versnelde ontsluiting van die jeug" die doel van hierdie koördinasie is, moet die godsdienstige vorming van die jeug dan nie ook aandag kry nie, aangesien die mens ook 'n godsdienstige wese is?

- Moet "opvoedende onderwys" nie ook voorsiening maak vir godsdiensopvoeding nie? Moet die leerders nie ten volle opgevoed word nie - dus ook in 'n godsdienstige $\sin$ ? $^{3}$

- Hoekom kom godsdiens as 'n faktor in die onderwys nie na vore in die lys van indikatore en faktore vir die struktuur en die aard

3 Die sogenaamde paideia-opvoedingsideaal is reeds deur die klassieke Griekse opvoeders erken; dit dui op die volronde ontwikkeling van die vollediggekultiveerde individu (Lucas, 1984:128). 
van die onderwysstelsel, soos gewoonlik aangebied deur onderwysstelselkundiges, nie?

Dit is moontlik dat godsdiens weens een of meer van die volgende redes nie as 'n determinant van die onderwysstelsel genoem word nie:

- Godsdiens en die etiese aspekte van die werklikheid word moontlik beskou as onderwerpe wat te "glibberig", te "moeilik" of te "persoonlik" van aard is om in die stelsel te akkommodeer, of om 'n onderwysstelsel daarvolgens in te rig of te struktureer.

- Godsdiens word moontlik beskou as behorende tot die metafisiese vlak van die werklikheid. In die harde, pragmatiese praktyk van die konstruksie van 'n onderwysstelsel het sulke metafisiese aspekte van die werklikheid nie regtig 'n plek nie. In die lig van die volgende uitspraak wat oor die metafisika gemaak word, is hierdie houding dalk verstaanbaar:

Metaphysics is that part of philosophy which has the greatest pretensions and is exposed to the greatest suspicions. Having the avowed aim of arriving at profound truths about everything, it is sometimes held to result only in obscure nonsense about nothing (Rée \& Urmson, 2005:242).

Die metafisika handel oor dinge "buite die fisiese" van die onderwysstelsel self (vgl. Mautner, 2001:351; Macey, 2001:250) en word derhalwe nie as relevant vir die "fisiese" van die onderwysstelsel beskou nie.

- Die toenemende invloed van die liberalisme, met sy dictum dat die mens in wese 'n individu is, en dat hierdie individu vry en selfwetgewend (outonoom) is, het waarskynlik ook tot hierdie tendens bygedra. Hierdie vrye mens, wat sy eie wetgewer is, het geen godsdienstige insig nodig om besluite oor die onderwysstelsel te kan neem nie.

- Die toenemende neiging om te konsentreer op die regte van die mens kon hierdie tendens versterk het. Volgens die Oxford Companion to Philosophy (Honderich, 2005:403) word dikwels aangevoer dat die mens oor hierdie regte beskik of daarop kan aanspraak maak, bloot omdat die mens méns is. In die proses word die legislator (die wetgewer) sowel as die verpligtinge van die mens wat met die regte gepaard behoort te gaan, misgekyk.

- Hoewel die miskenning van godsdiens as 'n faktor moontlik toegeskryf kan word aan die feit dat dit as 'n aspek van die meta- 
of buitefisiese (van die onderwysstelsel) beskou kan word, is daar 'n sterker moontlikheid dat die uitbanning daarvan as 'n faktor in die onderwysstelsel 'n gevolg van die intrede van die sekularisme was. Hierdie moontlikheid word in die volgende afdeling verder ondersoek.

\section{Die miskenning van godsdiens as 'n faktor in en van die onderwysstelsel as gevolg van toenemende sekularisme}

Om die tese te "bewys" dat toenemende sekularisme 4 moontlik 'n belangrike oorsaak is van die feit dat hoofstroomgodsdiens(te) as 'n faktor in en van die onderwysstelsel oor die hoof gesien word, moet 'n mens ietwat teruggaan in die geskiedenis. Gutek (1972:65), Mayer (1973:149), Wilds en Lottich (1970:165) en Mphahlele (1992:50-51) het reeds enkele dekades gelede daarop gewys dat die Christelike godsdiens - soos destyds in institusionele vorm veral vergestalt in die kerk - die onderwys geheel en al gedurende die Middeleeue oorheers het (vgl. ook Boyd \& King, 1975:99). Die Westerse Christendom, geïnstitusionaliseerd as die RoomsKatolieke Kerk, het gepoog om die Westerse beskawing te bewaar en te bevorder (Davies,1996:292). Om dit te kon bereik, het die kerk gefunksioneer soos 'n omvattende geestelike mag, en die beleidsrigtings daarvan het sterk sosiale, ekonomiese en politieke trefkrag op die destydse samelewing uitgeoefen (Roberts, 1983:304$305,469)$. Die mag van die kerk is veral op die terrein van die onderwys en onderwysinstansies gevoel (Power, 1970:295-330).

Klein kinders het hulle onderwys in die kategumeneskole begin; daarna is die onderwys óf in die buurtskole (kerk- of godsdiensskole waarin priesters gewerk het, en wat later in die plek van die kategumeneskole gekom het) óf in die katedraalskole voortgesit (Pistorius, 1982:86-88). Die katedraalskole was veral kenmerkend van biskoplike setels. Seuns wat later monnike wou word, sowel as ander wat nie tot 'n kerklike amp wou toetree nie, is toegelaat tot die monnikeskole (Duggan, 1916:81). Selfs die "sangskole" was aan die kerk verbonde: seuns uit arm gesinne is daar toegelaat met die oog daarop om hulle op te lei vir die sangdiens in die kerk. Hierdie chantry-skole was onder toesig van 'n priester en was bedoel vir die onderwys van kinders uit die adel. 
'n Mens merk egter reeds in die Middeleeue 'n tendens wat belangrik is vir die verdere ontplooiing van die skoolwese. Handelaars- en vakmansgildeskole het nie onder toesig van die kerk gestaan nie (Logue, 1960:46). Sommige adelikes het skole vir hulle eie kinders opgerig; in Ierland en Italië het grammatika-, regs- en geskiedenisskole só ontstaan. Teen die einde van die Middeleeue het daar ook allerlei burgerlike moedertaalskole ontstaan, en hulle is veral deur kinders uit die middelklas bygewoon. Kasteelskole vir dogters het gesorg vir hulle opleiding in etiket en fisiese opvoeding.

Die laasgenoemde tendens dui al in die rigting van die sekularisme wat gaandeweg in die onderwys ingetree het. Voordat daar aandag aan die sekularisme as sodanig geskenk kan word, moet eers kortliks gelet word op die aanvanklike pioniersituasie met betrekking tot die onderwys in Afrika (insluitende Suid-Afrika), en die VSA (om slegs twee sprekende voorbeelde te noem).

Die Keniaanse opvoedkundige Sifuna (1990:4-5) wys daarop dat inheemse onderwys in Afrika, dit wil sê vóór die koms van Westerse kolonialisme, 'n aantal gemeenskaplike doelstellings gehad het. Dit was in wese altyd opvoeding en onderwys "vir die lewe", en die doel daarvan was om die jongmense voor te berei vir volwassenheid. Die onderwys wat aan die jongmense gegee is, was deurweef met die totale sosiale lewe van die mense; wat aan hulle geleer is, is bepaal deur die sosiale konteks waarin hulle as volwassenes sou gaan leef. Afgesien daarvan dat daar aan hulle vaardighede oorgedra is wat hulle in toekomstige beroepe kon gebruik en in die politiek kon toepas, is daar ook godsdienstige, geestelike en morele waardes aan hulle geleer en voorgehou. Die volgende uitspraak van Sifuna (1990:6) maak dit duidelik dat die onderwys vóór die koms van Westerse invloede, volledig deurdrenk was van godsdienstige aspekte:

Indigenous education inculcated a religious attitude to life. Religion, which was concerned with morality, gave support to the laws and customs of the community and to its accepted rules of conduct which included courtesy, generosity and honesty ... [Children] learned upon which [religious] observances the welfare of the individual and the clan depended.

Hierdie integrering van die godsdienstige aspekte van menslike bestaan met die ander aspekte daarvan, insluitende die onderwys, vind 'n mens ook in ander pioniersgemeenskappe. Barnard (1979:38) wys daarop dat die onderwys deurdrenk was met godsdienstige invloede tydens die periode van die Groot Trek na die 
noorde onder die blankes in Suid-Afrika (1938-1850); die onderwys is in 'n groot mate bepaal deur die godsdiens. 'n Kenmerk van die pionier-Afrikaners, merk Barnard indertyd op, was hulle godsdienstige aard en die godvrugtige Christelike lewe wat hulle gelei het. Hierdie diepe godsdienssin het die ouers aangespoor om hulle kinders op te voed en voor te berei vir die aflegging van die Christelike geloofsbelydenis. Die primêre doel van die opvoeding en onderwys was "om die kinders te bring tot die selfstandige lees van die Bybel, en om hulle voor te berei tot kerklidmaatskap" (Barnard, 1979:37).

Dieselfde tendens vind 'n mens ook in koloniale Noord-Amerika, vóór die aanbreek van die 18de eeu. McCarthy, Oppewal, Peterson en Spykman (1981:81) is van mening dat die onderwys op hierdie stadium nog baie na aan die Middeleeuse benadering gestaan het, naamlik dat die godsdiens en die godsdienstige vorming van die leerders die kernbepaler van die onderwys moes wees. Daar was nog geen teken van 'n sekularistiese skeiding tussen byvoorbeeld openbare en privaatskole nie:

A common assumption throughout colonial New England was that the central purpose of human life, including education, was to promote the Christian faith and to advance the Christian life. ... The notion that it is desirable to separate religion from education, to make religion an entirely private matter by confining it to personal beliefs and to family and church matters, is a modern assumption that did not shape the educational theory of the early settlers (McCarthy e.a., 1981:80).

Hierdie skeiding het eers teen die einde van die 18de eeu ingetree, en het volledige beslag gekry in die 19de eeu (Neuhaus, 1987:5960). Voor die 18de eeu was alle leerinhoude en leermetodes deurdrenk van die Christelike lewensideaal. Een van die eerste rympies wat kinders byvoorbeeld uit die New England Primer moes leer lees en opsê was die volgende: "In Adam's fall, we sinned all". Volgens Gutek (1983:11) is dit 'n bewys van "the close relationship between reading and religion that was so dear to the Puritans" (vgl. ook Marsden, 1997:14 e.v. vir 'n volledige oorsig van hierdie geskiedenis).

Weens allerlei invloede, soos die aanvaarding van die liberalisme as lewenshouding en van 'n menseregtekultuur, onder meer weens die 
heersende Verligtingsdenke ${ }^{5}$, het daar aanvanklik in Westerse lande, maar gaandeweg ook wêreldwyd, 'n gees van sekularisme ingetree. Die woordeboekbetekenis van sekularisme is dat dit 'n leerstelling is wat godsdiens verwerp, in die besonder op die terrein van die etiek; en dat dit ook die standpunt behels dat godsdiens geen plek het in burgerlike aangeleenthede nie (Collins, 1999). Fowler (2002:34) brei op die tweede betekenis uit: "One of the greatest triumphs of secularism has been to banish belief in spiritual powers in relation to the world of secular reality, confining them to a separate realm." Van der Walt (1994:367) beaam hierdie sienings en is voorts ook van mening dat sekularisme gesien moet word as ' $n$ godsdiens of ideologie in eie reg, en selfs as die "moeder van alle ideologieë". Volgens Van der Walt6 is die sekularisme 'n religie, 'n ideologie of 'n alternatiewe lewensvisie wat die mag het om alle ander godsdienste uit die openbare domein van mense se lewens uit te ban, en om homself in hulle plek te plaas as die enigste openbaar aanvaarbare godsdiens.

Soos alle ander godsdienste, bepaal die sekularisme alles in die aanhanger daarvan se lewe en bestaan (Van der Walt, 2004:94). Ander hoofstroomgodsdienste, byvoorbeeld dié van die Christen of die Moslem, word beperk tot die persoonlike en private lewens van die aanhangers van daardie godsdienste (Van der Walt, 2004:91-93; 96). Tipies van die sekularisme, word daar 'n onderskeid gemaak tussen die openbare en die privaat sfere van mense se lewens. Ingevolge hiervan word alle hoofstroomgodsdienste en lewensbeskouings beskou as behorende tot die private sy van mense se lewens, en daardeur word hulle gestroop van alle magte in die openbare lewe (Van der Walt, 2004:93, 95).

Sekularisme, soos hierbo beskryf, het homself gevestig as 'n wêreldwye "godsdiens"; gevolglik het dit ook wêreldwyd kenmerkend geword van onderwysstelselbeplanning. Sekularisme het die spirituele element geword waarin mense deesdae leef en bestaan die godsdiens en die daaglikse praktyk van die massas (Van der Walt, 2004:93). Die mens het die norm vir alles geword, die mens is

5 Dit is die tendens om alles suiwer rasionalisties te benader. Dit is 'n tendens wat sedert die bydraes van die Duitse filosoof, Immanuel Kant, veral in die Westerse wêreld posgevat het.

6 Die besinnings oor die (humanistiese) sekularisme by Mouw en Griffioen (1994:49 e.v.), Edlin (1999:44-45, 106, 139, 229, 237) en Pike (2004:149 e.v.) kom in 'n groot mate ooreen met dié van Van der Walt (2004; 2004b en 2005). 
die skepper van alle dinge, insluitende die staat en owerheid, wetgewing, staatsbeleid (ook dié oor die onderwys) en opvoeding alles is geskep na die hedendaagse mens se eie humanistiese, selfgesentreerde beeld. Sekularisme word ook gekenmerk deur die privatisering van alle ander (hoofstroom-)godsdienste en lewensvisies, en dit skep 'n onderskeid en selfs skeiding tussen dit wat as die openbare en die private sfere van die mens se lewe beskou kan word. Volgens hierdie denke behoort die staat, die staatsowerheid en die openbare onderwys tot die openbare sfeer van die lewe, terwyl godsdiens, gebed, sang en die kerk geag word as behorende tot die private en persoonlike sfeer van die mens se lewe (Colson \& Pearcey, 2001:19, 30, 37 en veral 39). Hierbenewens word die sekularisme volgens Van der Walt (2004) ook gekenmerk deur die vervanging van beginsels en norme deur "persoonlike waardes", en ook deur naakte materialisme.

Volgens Van der Walt (2003:132-133) lei hierdie dubbelverdiepingof dualistiese siening van die sekularisme tot die volgende:

Christene [en ander hoofstroomgodsdienste] se religieuse verhouding tot God [of watter god ook al aangehang word] word dus geduld maar 'geprivatiseer' ... Die Christelike getuienis in die openbare lewe word beperk tot die mate waarin dit 'n bydrae tot morele vraagstukke kan bied.

Vir die onderwysstelsel en onderwysstelbeplanning hou die aanvaarding van die sekularisme as 'n nuwe "godsdiens" en "lewensvisie" verskeie gevolge in. 'n Mens sou kon waag om te sê dat feitlik die hele ontwikkelde en ontwikkelende wêreld die neiging getoon het om die voorbeeld van die Amerikaners te volg in onderwysstelselbeplanning vanaf die begin van die 19de eeu. In die koloniale tydperk (tot ongeveer die 18de eeu) was die sekularisme nie ' $n$ bekende verskynsel nie. Daar is egter wel in die onderwysstelsel voorsiening gemaak vir twee soorte skole: openbare of publieke skole, en privaatskole. Die onderskeid is meer gegrond op die ontstaan, oprigting, bestuur en beheer van die skole, en nie soseer op hulle befondsing nie. Alle skole is tot op daardie stadium eenders deur die staatsowerheid befonds. Openbare skole was tipies skole wat deur die staatsowerheid opgerig en bestuur is, en privaatskole is deur ander organisasies, soos kerke, opgerig en bestuur. In beginsel was daar egter geen grondliggende verskil tussen die twee soorte skole nie.

Die onderskeid tussen die twee soorte skole het egter in die tweede helfte van die 18de eeu verdiep tot 'n prinsipiële skeiding. Dié 
verandering het gepaard gegaan met veranderinge in die samelewing van die na-Revolusionêre tydperk, en kan ook moontlik toegeskryf word aan die invloed van die Verligting, waarvan Thomas Jefferson 'n eksponent was. Jefferson het vanaf 1779 verskillende vorms van wetgewing in sy tuisstaat, Virginië, deurgevoer. Daarmee het hy onder andere die Anglikaanse Kerk in Virginië sy stewige staanplek in die openbare lewe laat verloor. Die Anglikaanse Kerk is byvoorbeeld hierna nie meer erken as staatskerk nie. Ander stukke wetgewing het die onderskeid tussen openbare- en privaatskole geëksploiteer. Jefferson het byvoorbeeld aangevoer dat die openbare skole 'n belangrike rol moet vervul in die bevordering van die nasionale (republikeinse) ideale. Die openbare skool moes verhewe wees bo die "sektariese" gestry tussen die kerke en tussen die godsdienste; dit moes bo hierdie kleinlike godsdienstige toutrekkery uitstyg en moes vashou aan waardes en norme wat deur alle Amerikaanse burgers aanvaar sou word.

Die sekularistiese onderskeid (selfs skeiding) tussen 'n openbare godsdiens ('n stel waardes wat bo kerklike en godsdienstige verskille uitgaan) en private, "sektariese" godsdienste (soos beoefen deur die kerke en deur mense in hulle private lewens) was 'n kernpunt van Jefferson se denke. Weens sy Verligtingsdenke was sy vertrekpunt dat daar 'n gemeenskaplike openbare godsdiens behoort te wees wat gebou is op ' $n$ soort universele moraliteit - 'n moraliteit of godsdiens waaraan alle regdenkende (rasionele) Amerikaners kon vashou. In alle godsdienste, het hy gemeen, is daar gemeenskaplike elemente, en dié kan saamgevoeg word in ' $n$ universele openbare godsdiens wat almal kan beoefen en aanhang.

Die privatisering van die ander, "sektariese" godsdienste is nie op die Amerikaanse bevolking afgedwing nie. Dit het spontaan gebeur as gevolg van, onder meer, die Groot Ontwaking7. In die Ontwaking het die gedagte van godsdienstige individualisme posgevat: mense het heeltemal vrywillig begin glo dat godsdiens en godsdienstige belewing beperk was tot ' $n$ mens se persoonlike en individuele verhouding met God in die private sfere van die gesin en die kerk. McCarthy e.a. (1981:83) skryf hieroor die volgende:

7 Die Groot Ontwaking was 'n algemene spirituele ontwaking of oplewing binne die evangeliese godsdienstige tradisie in die Noord-Amerikaanse kolonies, en wat sy hoogtepunt teen die 1740's bereik het. Dit het onstaan weens, onder meer, die prediking van die kongregasionalistiese teoloog Jonathan Edwards en die evangelis George Whitefield, wat albei gewys het op die noodsaaklikheid vir sondaars om hulle van hulle sondige weë te bekeer. 
... the Christian community accepted a dualist view of life in which a so-called secular realm existed alongside a religious realm. This division of life into two separate spheres conveniently matched Jefferson's distinction between private sectarian and public nonsectarian morality.

Met hierdie waarneming onderstreep McCarthy en andere die opmerking van Van der Walt waarna hierbo verwys is, naamlik dat die sekularisme die enigste erkende openbare godsdiens geword het (vgl. ook Barbour, 1997; De Ruyter, 1994; Marsden, 1997).

'n Soortgelyke proses het hom ook in ander lande voltrek. Die monopolie van die kerk op die onderwys is gaandeweg ondermyn. 'n Belangrike bydraende faktor tot hierdie verskynsel was die skepping van staatsonderwysstelsels in die 19de eeu, byvoorbeeld deur middel van die Guizotwet in Frankryk in 1830 en die Fosterwet in Engeland in 1870. Kerkskole het bly voortbestaan naas staatskole. Laasgenoemde het aanvanklik 'n Christelik-godsdienstige etos gehad, maar hulle etos het veral na die Tweede Wêreldoorlog onder druk gekom. Die hoofredes daarvoor was die toenemende multikulturele (insluitende multireligieuse) samestellings van die bevolkings van dié lande (vgl. Steyn \& Wolhuter, 2000:24-25) en die opkoms van 'n kultuur van menseregte. Nog 'n faktor was die toenemende getal sogenaamde a-religieuse mense in dié lande. Slegs $21 \%$ en $59 \%$ van die bevolkings van onderskeidelik Europa en die VSA beskou hulself tans nog as gelowig (Rushdie, 2005:16). Die toenemende multikulturele samestelling van die lande het daartoe gelei dat godsdiensonderrig, waar dit nog aangebied is, 'n verandering ondergaan het. Die veranderings was vanaf onderrig in die beginsels van die Christelike geloof met die oog op belydenisaflegging van dié geloof, tot 'n meer generiese soort godsdienskunde, wat gerig was op die bekendstelling van die hoofgodsdienste van die wêreld, asook met die oog op die bevordering van interkulturele begrip en die ontwikkeling van verhoudings (vgl. Jackson, 2004:3-14). Die Swann-verslag (1984) oor multikulturele onderwys in die Verenigde Koninkryk bevat byvoorbeeld 'n hele hoofstuk oor Godsdienswetenskap as skoolvak (vgl. Department of Education and Science and the Welsh Office, 1986:465-520).

Dieselfde patroon doen hom in die Ooste voor. In die Asiatiese lande (soos Thailand, Maleisië, Singapoer, Indonesië en Korea) word onderwys tot so 'n mate as instrument vir ekonomiese groei en modernisasie aangewend, dat godsdiensonderrig uitgeskuif word. Artikel 9 van die grondwet van Japan verbied byvoorbeeld die 
onderrig van enige "sektariese" godsdiens in 'n staatskool (Pretorius, 1995:340), terwyl artikels 29 en 30 van die grondwet van Indië enige godsdiensonderrig in 'n openbare skool verbied (Rolly, 2005:4).

Hierdie kort oorsig van die onderwysgeskiedenis in Noord-Amerika en in ander dele van die wêreld lei 'n mens tot 'n paar voorlopige gevolgtrekkings:

- Die onderskeid tussen openbare en privaatskole is op sigself ' $n$ aanvaarbare verskynsel. Die onderskeid dui bloot op verskille in oprigting en bestuur, en nie noodwendig op befondsing nie.

- Die onderskeid tussen openbare en privaatskole het weens bepaalde veranderings in die Amerikaanse samelewing verdiep tot 'n skeiding tussen die twee soorte skole, en tot die assosiasie van die openbare skole met die sekularistiese godsdiens van 'n algemene of universeel gehuldigde moraliteit.

- Onderwysstelselbeplanning is dikwels ook 'n funksie van veranderings en verskuiwings in 'n samelewing. In die geval van Amerika is dit veral beïnvloed deur die koms van die Verligting, die Liberalisme en die Groot Ontwaking.

- Volgens die sekularistiese siening is die sekularisme die enigste "godsdiens" wat in die openbare domein van die lewe toelaatbaar is, aangesien dit slegs algemeen aanvaarbare norme vir moraliteit behels en erken. Alle ander godsdienste word beskou as "sektaries", dit wil sê, hulle werk verdelend en groepvormend. So ' $n$ verdelende opset word nie beskou as bevorderlik vir die nastrewing van nasionale ideale nie.

- Die Amerikaanse voorbeeld is sedertdien wêreldwyd nagevolg. Behalwe in enkelgodsdienslande (byvoorbeeld waar Islam as enigste staatsgodsdiens erken word) word die sekularisme as die openbare godsdiens aanvaar, en ander (hoofstroom-)godsdienste beperk tot die private sfeer van mense se lewens.

- 'n Mens sou, op grond van die bespreking van die sekularisme hierbo, die gevolgtrekking kon maak dat godsdiens wel nog 'n faktor in onderwysstelselbeplanning is, mits daardie godsdiens die sekularisme is. Ander, sektariese, hoofstroomgodsdienste speel nie meer ' $n$ rol in onderwysstelselbeplanning nie.

- In lande waar die sekularisme hoogty vier, word hoogstens aandag aan drie sake gegee wat met ander, "sektariese", hoofstroomgodsdienste verband hou: (a) om die reg tot godsdiensvryheid op die een of ander manier te verskans; (b) om 
die waardes voortvloeiend uit die sekularisme, en wat as universeel aanvaarbaar geag word, te formuleer, en (c) om, waar moontlik, die "sektariese" (private) godsdienste in die openbare skoolstelsel te probeer akkommodeer.

\section{Gevallestudie: Suid-Afrika}

Anders as in die periode vóór 1994 toe die Suid-Afrikaanse onderwysstelsel beplan en bestuur is asof Suid-Afrika 'n enkelgodsdienstige Christelike 8 land was (vgl. Wet 39 van 1967, en ook die soortgelyke wette vir die sogenaamde nie-blanke bevolkingsgroepe; vgl. Behr, 1984:163 e.v.), is Suid-Afrika na 1996 as 'n tipiese sekularistiese staat ingerig. Die Grondwet (Wet 108 van 1996) bevat ' $n$ handves van menseregte wat ' $n$ weerspieëling is van die regte wat enkelinge en groepe behoort te kan geniet in 'n regstaat. Hierdie regte is ook veronderstel om universeel aanvaarbaar te wees - hulle verteenwoordig ' $n$ veronderstelde universele moraliteit en waardestelsel. Al die onderwyswette wat ná 1996 gepromulgeer is, is gefundeer in hierdie algemene sekularistiese moraliteit. Geen wet wat ná 1996 gepromulgeer is, verwys op enige manier na die een of ander hoofstroomgodsdiens nie. Dit is verstaanbaar, aangesien sodanige verwysing op die bevoorregting van een bepaalde godsdiens sou gedui het, en téén die nastrewing van nasionale doelwitte sou gewerk het. Die enigste godsdiens wat wel in die openbaar aangehang word, is die sekularisme. Die "beoefening" van hierdie "godsdiens" geskied egter stilswyend. 9

Hierdie prentjie het egter ook 'n ander kant. Elke burger in die land het die reg tot vryheid van beweging, mening, assosiasie en godsdiens. Daarmee word te kenne gegee dat elke burger die reg het om as enkeling en as groep of gemeenskap in private of persoonlike hoedanigheid die een of ander godsdiens, anders as die sekularisme, te beoefen. Die Suid-Afrikaanse Skolewet (Wet 84 van 1996) bepaal dat ouers die meerderheid van 'n skoolbeheerliggaam moet vorm en dat skoolbeheerrade onder meer (artikel 13)

8 Suid Afrika was destyds al een van die mees godsdienstig-pluriforme lande ter wêreld (Tellinger, 2005:257).

9 'n Mens vind in geen amptelike publikasie van die owerhede in Suid-Afrika 'n verwysing na die sekularisme nie. In die Manifesto on Values, Education and Democracy (2001) word ook geen melding gemaak van enige verbintenis tot 'n bepaalde hoofstroomgodsdiens nie (Ministerie van Onderwys, 2001:5). 
skoolbeleid met betrekking tot godsdiensbeoefening, asook die skool se missie en doelstellings, kan formuleer (Republic of South Africa, 1996). Dié bevoegdhede wat die minister van onderwys ingevolge die Nasionale Wet op Onderwysbeleid (Wet 27 van 1996) in die godsdiensbeleid van 2003 geproklameer het, is egter eng omskryf. Die skoolvak Godsdienskunde (Religion Education) word kragtens die gewysigde Nasionale Kurrikulumverklaring as deel van die vak Lewensoriëntering aangebied (Department of Education, 2003). Die doel van dié vak is om leerders bekend te stel aan die hoofgodsdienste van die wêreld, en nie die verwerwing van 'n bepaalde godsdiens deur die leerders nie (Department of Education, 2003). Volgens die gemelde beleid is godsdiensonderrig met die oog op godsdiensverwerwing hoofsaaklik die taak van die ouerhuis (vgl. Republiek van Suid-Afrika, 2003). Beheerrade van openbare skole mag volgens die beleid skoolfasiliteite beskikbaar stel vir geloofsbeoefening, op die basis van vrye en vrywillige assosiasie, en op voorwaarde dat fasiliteite vir alle geloofsgroeperinge op 'n gelyke basis beskikbaar gestel word. Skoolbyeenkomste het die potensiaal om eenheid in verskeidenheid te bevestig en moet vir dié doel aangewend word. Openbare skole mag volgens dié beleid nie die religieuse vryheid van leerders skend deur 'n religieuse eenvormigheid op 'n skool af te dwing nie. Waar geloofsbeoefening deel is van skoolbyeenkomste, moet leerders verskoon kan word op grond van gewetensbesware en moet gelyke alternatiewe reëlings vir hulle getref word.

Slegs in privaat omstandighede of hoedanigheid kan die een of ander "sektariese" hoofstroom- of ander godsdiens beoefen word. Dit kan geskied op voorwaarde dat die beginsels van so 'n privaat of "sektariese" godsdiens nie oorgedra word na die openbare lewe nie (vgl. Republiek van Suid-Afrika, 2003). Christelike ouers kan daarom byvoorbeeld nie daarop aandring dat die visie, missie, doel en beleid van die openbare skool wat hulle kinders besoek in Christelike terme geformuleer word nie. (Dit mag hulle wel doen in die geval van 'n privaatskool, maar dan betaal hulle ook die meeste van die koste om die skool aan die gang te hou.) "Sektariese vorms van godsdiens" word nie meer as 'n betekenisvolle faktor in en vir onderwysstelselbeplanning in die openbare skoolstelsel erken nie (dog wel nog in 'n mate in private onderwys, hoewel laasgenoemde ook onder wetlike bepalings van die owerheid staan).

Die uiteensetting hierbo het ten minste twee implikasies vir die onderwys in Suid-Afrika: 
- Ten eerste het dit implikasies vir die waardestelsel wat aangehang en bevorder moet word. 'n Ontleding van die Manifesto on Values, Education and Democracy (Ministerie van Onderwys, 2001) toon dat hierdie publikasie van die Nasionale Ministerie van Onderwys slegs op daardie waardes konsentreer waarmee alle Suid-Afrikaners dit met mekaar eens behoort te wees. Dit is duidelik (a) dat slegs waardes uitgesoek is wat relatief "leeg" aan betekenis en inhoud is, en wat elkeen vir homof haarself met betekenis moet vul; (b) dat dit slegs "waardes" bevat, en nie byvoorbeeld "sektaries"-godsdienstig gefundeerde beginsels en norme nie; (c) dat die "waardes" ooreenstem met die uitgangspunte en oogmerke wat in die Grondwet gepromulgeer is, en (d) dat die waardes uitdrukking gee aan 'n gedeelde of universele moraliteit.

- Dit het ook 'n tweede implikasie. Die opmerking is reeds hierbo gemaak dat hedendaagse sekularistiese state en hulle owerhede nie "sektariese", hoofstroomgodsdienste as faktore in onderwysstelselbeplanning erken nie, maar dat hulle wel die een of ander plan probeer bedink om hierdie "sektariese" godsdienste in die openbare skoolstelsel te akkommodeer. Die wyse waarop hierdie proses in Suid-Afrika verloop het, is ' $n$ voorbeeld van hoe dit kan gebeur. Dit is opmerklik dat daar 'n gesprek, en selfs stryd tussen die onderwysowerheid (as beskermheer van die sekularistiese godsdiens) en die verteenwoordigers van die hoofstroomgodsdienste plaasgevind het, wat geduur het vanaf ongeveer 1994 tot 2003, voordat die onderwysowerheid met 'n beleid oor "godsdiens en onderwys" in 2003 vorendag kon kom. Dit gaan nie in hierdie beleid oor hoe godsdiens 'n betekenisvolle rol in die onderwysstelsel kan speel nie, maar wel oor hoe die verskillende "sektariese", private godsdienste in die onderwysstelsel geakkommodeer kan word, sonder om die openbare skoolstelsel te affekteer of rigtingbepalend daarvoor te wees. Daarom stel die beleidsopstellers voor (Republiek van Suid-Afrika, 2003:8) dat 'n koöperatiewe model10 gevolg moet word. Dié model word soos volg omskryf:

10 Die onderwysowerhede het die keuse tussen die volgende modelle gehad: die repressiewe model (alle "sektariese" godsdienste word onderdruk en totaal uit die openbare onderwysstelsel geban); die separatistiese model (geen poging word aangewend om die godsdienste wat die burgers aanhang en beoefen in die openbare skoolstelsel te akkommodeer nie); die neutrale model (die openbare skool word so neutraal en onbetrokke as moontlik jeens alle "sektariese" godsdienste gehou); die teokratiese model (een bepaalde godsdiens word as die nasionale godsdiens aanvaar, en word dus ook as 
In a co-operative model, both the principle of legal separation and the possibility of creative interaction are affirmed. Separate spheres for religion and the state are established by the Constitution, but there is scope for interaction between the two. While ensuring the protection of citizens from religious discrimination or coercion, this model encourages an ongoing dialogue between religious groups and the state in areas of common interest and concern. Even in such exchanges, however, religious individuals and groups must be assured of their freedom from any state interference with regard to freedom of conscience, religion, thought, belief and opinion.

Op grond van hierdie model maak die beleid voorsiening vir die volgende:

- Godsdienskunde of -wetenskap as 'n gewone skoolvak, waarvan die leerinhoude akademies van aard is en wat bemeester moet word vir eksamendoeleindes.

- Godsdiensonderrig, wat 'n vormende vak is, en derhalwe nie deel van die formele kurrikulum nie, maar waarvoor op die een of ander manier voorsiening gemaak moet word by die skool.

- Godsdienstige plegtighede, waarvoor die skool ook op die een of ander manier voorsiening behoort te maak, en wat ook nie deel vorm van die formele kurrikulum nie.

\section{Slotsom en aanbeveling}

Met slegs enkele uitsonderings (byvoorbeeld in enkelgodsdiensMoslemlande) word godsdiens in die hedendaagse ontwikkelde en ontwikkelende wêreld in net één vorm, naamlik die openbare "godsdiens", die sekularisme, beskou as 'n faktor wat 'n rol kan speel in onderwysstelsels en onderwysstelselbeplanning. Omdat die sekularisme alle ander hoofstroom-, "sektariese" godsdienste uit die openbare lewe verdring het na die private en persoonlike sfere van mense se lewens, kan dié godsdienste nie meer 'n betekenisvolle rol in die openbare onderwys speel nie. Omdat die sekularisme die gedagte beliggaam dat daar ' $n$ openbare moraliteit en universeel gedeelde waardes is wat alle burgers in 'n bepaalde land of samelewing met mekaar kan deel en bevorder, gebeur dit dat hierdie waardes gewoonlik opgeneem word in die grondwette van

amptelike godsdiens in en vir die skoolstelsel beskou); en die koöperatiewe model (daar is 'n vorm van samewerking tussen die openbare skoolstelsel en die verskillende "sektariese" godsdienste; laasgenoemde moet op 'n manier in die skole geakkommodeer word). 
lande (implisiet of eksplisiet), en ook in ander wetgewing, en dat dit dan juis hierdie waardestelsel is wat op die een of ander manier deur die openbare onderwys bevorder moet word. In sommige gevalle, soos die Suid-Afrikaanse gevallestudie getoon het, word daar tog ook moeite gedoen om die private, "sektariese" hoofstroomgodsdienste op die een of ander manier in die openbare onderwysstelsel te akkommodeer. Sorg word egter deur beleidmaking en wetgewing gedra dat sulke private, "sektariese" godsdienste nie die openbare "godsdiens" - sekularisme - verdring nie. Hoewel die private "sektariese" godsdienste dus wel geakkommodeer (kan) word, gebeur dit buite die formele kurrikulum om. Openbare sekularistiese waardes kry 'n plek binne die kurrikulum, en moet daar bevorder word, soos die Manifesto on Values, Education and Democracy (Ministerie van Onderwys, 2001) aandui. Hierteenoor geniet private waardes slegs buitekurrikulêre status.

'n Mens sou die gedagtegang in hierdie artikel kon problematiseer deur te vra wat sou gebeur indien sulke "sektariese" hoofstroomgodsdienste wel as 'n faktor in onderwysstelsels en onderwysstelselbeplanning erken en toegepas word. Een antwoord op hierdie vraag is dat erkenning van die verskillende hoofstroomgodsdienste in die onderwysstelsel moontlik wel verdelend onder landsburgers sou kon werk, en dat die strewe om alle leerders 'n enkele stel nasionale waardes en openbare moraliteitseise met mekaar te laat deel, laat vaar sou moet word. So 'n benadering kan inderdaad nadelig wees vir die bou van 'n gemeenskaplike nasiebesef en -gevoel en burgerskap (patriotisme). Aan die ander kant hoef dit nie noodwendig so 'n versplintering tot gevolg te hê nie. $\mathrm{Na}$ uitvoerige empiriese ondersoek oor hierdie vraagstuk in Nederland $\mathbf{1 1}$ is bevind dat alle skole, of hulle openbaar of privaat/ onafhanklik is, onvermydelik die een of ander stel lewensbeskoulike waardes of beginsels huldig, en dat gesê kan word: Alle onderwijs is bijzonder - elke skool en elke vorm van onderwys is lewensbeskoulik uniek (Miedema \& Vroom, 2004). Strietman (2005) sluit hierby aan met sy waarneming dat "alle onderwys (skole) werk aan waardes". Indien dit dan die geval is, behoort elke skool, hetsy openbaar of onafhanklik (privaat), toegelaat te word om te werk aan 'n eie waardestelsel, afgesien daarvan of die waardes voortvloei uit die een of ander hoofstroomgodsdiens en die leerstellinge daarvan,

11 Vergelyk Dijkstra en Miedema (2003) vir 'n volledige uiteensetting van die ondersoek en die bevindings. 
en of dit voortvloei uit 'n ander lewensbeskoulike bron (soos die sekularisme).

In beginsel behoort dit dus nie nodig te wees vir onderwysstelselbeplanners om die hoofstroomgodsdienste as faktor uit hulle beplanning weg te laat nie. Die insluiting daarvan sal juis sin gee aan die oproep in die Manifesto on Values, Education and Democracy (Ministerie van Onderwys, 2001:5):

The objective - though it is really the start of a new journey - is that every single institution in the country will have a Values Statement and a Values Action-Plan, and a shared commitment to them.

Hierdie oproep maak slegs sin as elke skool toegelaat word om self te besluit wat die "waardes" vir die betrokke skool moet wees. Hoewel só 'n praktyk dalk nie bevorderend sal wees vir die uitlewing van gedeelde nasionale waardes en gedeelde openbare moraliteit nie, sal dit verseker dat die onderwysstelsel beter onderwys sal kan bied. Per slot van rekening kan die opvoedingsgehalte van onderwys direk in verband gebring word met die godsdienstige en lewensbeskoulike waardes wat die opvoeders huldig en van waaruit hulle met die leerders in interaksie tree.

\section{Geraadpleegde bronne}

ARENDS, R.I., WINITZKY, N.E. \& TANNENBAUM, M.D. 1998. Exploring teaching. Boston: McGraw-Hill.

BAKKER, C.B. 2004. Demasqué van het christelijk onderwijs? (Unmasking Christian education.) Faculty of Theology: University of Utrecht. (Utrechtse Theologische Reeks. Publicaties vanwege de faculteit Godgeleerdheid van de Universiteit Utrecht. Part 46. ISBN 90-72235-48-7.)

BARBOUR, I.G. 1997. Religion and science, historical and contemporary issues. San Francisco: Harper.

BARNARD, S.S. 1979. Blanke-onderwys in Transvaal. Durban: Butterworths.

BEHR, A.L. 1984. New perspectives in South African education. Durban: Butterworths.

BENNETT, J.A. 1995. Belize. (In Postlethwaite, T.N., ed. International encyclopedia of national systems of education. 2nd ed. Oxford: Permagon. p. 92-98.)

BONDESIO, M.J. \& BERKHOUT, S. 1987. Onderwysstelselkunde. Pretoria: Gutenberg.

BOYD, W. \& KING, E.J. 1975. The history of western education. London: Black.

COLLINS CONCISE DICTIONARY. 1999. Glasgow: HarperCollins.

COLSON, C. \& PEARCEY, N. 2001. The Christian in today's culture. Wheaton: Tyndale House. 
CRELLIN, C.T. 1995. Bhutan. (In Postlethwaite, T.N., ed. International encyclopedia of national systems of education. 2nd ed. Oxford: Permagon. p. 103-109.)

DAVIES, N. 1996. Europe: A history. Oxford: Oxford University Press.

DE RUYTER, D. 1994. Op weg naar een nieuwe staatspedagogiek? (In Miedema, S. \& Klifman, H. Christelijk onderwijs in ontwikkeling. Kampen: Kok. p. 23-29.)

DEPARTMENT OF EDUCATION. 2003. Revised National Curriculum Statement. http:/education.pwv.gov.za [24 Oct. 2005].

DEPARTMENT OF EDUCATION AND SCIENCE AND THE WELSH OFFICE. 1986. Education for all: The report of the Committe of Inquiry into the Education of Children from Ethnic Minority Groups (Swann report). London: HMSO.

DEPARTMENT OF EDUCATION AND SCIENCE AND THE WELSH OFFICE (United Kingdom). 1989. Discipline in schools: report of the Committee of Inquiry chaired by Lord Elton. London: HMSO.

DIJKSTRA, A.B. \& MIEDEMA, S. 2003. Bijzonder gemotiveerd. Assen: Koninklijke Van Gorcum.

DUGGAN, S.P. 1916. A student's textbook in the history of education. New York: Appleton-Century.

EDLIN, R. J. 1999. The cause of Christian education. Adelaide: National Institute of Christian Education.

FOWLER, S. 2002. The Christian professional called to the service of love. Melbourne: Amani Educational Services.

GUTEK, G.L. 1972. A history of the Western educational experience. New York: Random House.

GUTEK, G.L. 1983. Education and schooling in America. Englewood Cliffs: Prentice-Hall.

HONDERICH, T., ed. 2005. The Oxford companion to philosophy. Oxford: Oxford University Press.

JACKSON, R. 2004. Intercultural education and recent European pedagogies of religious education. Intercultural Education, 15(1):1-14.

LEMMER, E.M. 1995. The education system of the People's Republic of China. (In Dekker, E.I. \& Van Schalkwyk, O.J., eds. Modern education systems. Durban: Butterworths. p. 271-315.)

LOGUE, G. 1960. Aims and methods of Western education. Cape Town: Juta.

LUCAS, C.J. 1984. Foundations of education. Englewood Cliffs: Prentice Hall.

MAARMAN, R.F.A., STEYN, S.C. \& WOLHUTER, C.C. 2006. Optimale inagneming van demografiese gegewens in onderwysbeplanning in Suid-Afrika. South African Journal of Education, (in proses om gepubliseer te word).

MACEY, D. 2001. The Penguin dictionary of critical theory. London: Penguin.

MARSDEN, G.M. 1997. The outrageous idea of Christian scholarship. New York: Oxford University Press.

MAUTNER, T. 2001. Dictionary of philosophy. London: Penguin.

MAYER, F. 1973. A history of educational thought. Columbus: Merrill.

MCCARTHY, R., OPPEWAL, D., PETERSON, W. \& SPYKMAN, G. 1981. Society, state and schools. Grand Rapids: Eerdmans.

MIEDEMA, S. \& VROOM, H., reds. 2004. Alle onderwijs bijzonder: Levensbeschouwelijke waarden in het onderwijs. Zoetermeer: Meinema.

MINISTERIE VAN ONDERWYS. 2001. Manifesto on values, education and democracy. Pretoria. 
MOUW, S. \& GRIFFIOEN, S. 1993. Pluralisms and horizons. Grand Rapids: Eerdmans.

MPHAHLELE, M.C.J. 1992. Education through the ages. Pretoria: HAUM.

MURRAY, S. 2002. Democratic values, humanism and African language learning. Perspectives in Education, 20(1):111-121.

NEUHAUS, R.J. 1987. Democracy and the renewal of public education. Grand Rapids: Eerdmans.

PIKE, M.A. 2004. The challenge of Christian schooling in a secular society. Journal of Research in Christian Education, 13(2):149-166), Fall.

PISTORIUS, P. 1982. Gister en vandag in die opvoeding. Potchefstroom: Pro Rege.

POWER, E.J. 1970. Main currents in the history of education. New York: McGraw-Hill.

PRETORIUS, S.G.1995. The education system of Japan. (In Dekker, E.I. \& Van Schalkwyk, O.J., eds. Modern education systems. Durban: Butterworths. p. 317-365.)

RÉE, J. \& URMSON, J.O. 2005. The concise encyclopedia of Western philosophy. London: Routledge.

REPUBLIC OF SOUTH AFRICA. 1996. South African Schools Act (Act 84 of 1996). Pretoria: Government Printer.

REPUBLIC OF SOUTH-AFRICA. 2003. National Education Policy Act, 1996 (27 of 1996): National Policy on Religion and Education. Staatskoerant, 459(25459), Sept. 12.

ROBERTS, J.M. 1983. The Pelican history of the world. Harmondsworth: Penguin.

ROLLY, H.F. 2005. Approaches of comparative and international education to educational rights of minorities.(In Genov, N., ed. Ethnicity and educational policies. Berlin: Institute of Eastern European Studies. p. 22-36.)

RUSHDIE, S. 2005. Beware those who seek to deny us our right to freedom from religion. Sunday Times, March 27.

SIFUNA, D.N. 1990. Development of education in Africa. Nairobi: Initiatives.

STEYN, H.J., STEYN, S.C., DE WAAL, E.A.S. \& WOLHUTER, C.C. 2002. Die onderwysstelsel: struktuur en tendense. Noordbrug: Keurkopie.

STEYN, H.J., STEYN, S.C., DE WAAL, E.A.S. \& WOLHUTER, C.C. 2003. Die Suid-Afrikaanse onderwysstelsel: Kernkenmerke. Noordbrug: Keurkopie.

STEYN, H.J. \& WOLHUTER, C.C. 2000. The education system and probable societal trends of the twenty-first century. (In Steyn, H.J. \& Wolhuter, C.C., eds. Education systems of emerging countries: Challenges of the $21 \mathrm{st}$ century. Noordbrug: Keurkopie. p. 1-40.)

STONE, H.J.S. 1981. The common and the diverse: A profile of comparative education. Isando: McGraw-Hill.

STRIETMAN, H. 2005. Alle onderwijs werkt aan waarden: Ook de openbare school bijzonder. (All schools have to deal with values: also the public school is a special school.) SBM-Maandblad van de Besturenraad voor Managers, Bestuurders en Toezichthouders, (8):18-19, April 8.

STURM, J., GROENENDIJK, L., KRUITHOF, B. \& RENS, J.A. 1998. Educational pluralism - a historical study of so-called "pillarization" in the Netherlands, including a comparison with some developments in South African education. Comparative Education, 34(3):281-297.

TALBANI, A. 1996. Pedagogy, power and discourse: transformation of Islamic education. Comparative Education Review, 40(1):66-82. 
TELLINGER, M. 2005. Slave species of god. Johannesburg: Music Master's Books.

TERVOORT, A. 2005. 125 jaar Vrije Universiteit, wetenschap en samenleving. Amsterdam: Vrije Universiteit.

VAN BRUMMELEN, H. 1989. The new Christian right and North American education. Potchefstroom: IRS. (No. 258.)

VAN DEN BERG, J.S., red. 1992. Een onderwijsbestel met toekomst ... Amersfoort: Unie voor Christelijk Onderwijs.

VAN DER WALT, B.J. 1994. The liberating message. Potchefstroom: IRS.

VAN DER WALT, B.J. 2003. Identiteit en relevansie. Tydskrif vir Christelike Wetenskap, 39(3 \& 4):131-148.

VAN DER WALT, B.J. 2004. Sekularisme, die gees van ons tyd - 'n bedreiging 1. Tydskrif vir Christelike Wetenskap, 40(1 \& 2):85-97.

VAN DER WALT, B.J. 2004b. Sekularisme, die gees van ons tyd - 'n bedreiging 2. Tydskrif vir Christelike Wetenskap, 40(3 \& 4):93-113.

VAN DER WALT, B.J. 2005. Sekularisme, die gees van ons tyd. Tydskrif vir Christelike Wetenskap, 41(1 \& 2):43-74.

VAN SCHALKWYK, O.J. 1981. Fokus op die onderwysstelsel. Durban: Butterworths.

VAN SCHALKWYK, O.J. 1995. Introduction: some thoughts on education systems. (In Dekker, E.I. \& Van Schalkwyk, O.J., eds. Modern education systems. 2nd ed. Durban: Butterworths. p. 1-45.)

VOS, A.J. \& BARNARD, S.S. 1984. Comparative and international education for student teachers. Durban: Butterwoths.

WEIGAND-TIMMER, H.A.C. 2005. Leren bij het leven. Voordrag by: Studiedag Open Universiteit over Levensbeschouwing en Onderwijs. 23 April. Utrecht: Studiecentrum van de Open Universiteit.

WILDS, E.H. \& LOTTICH, K.V. 1970. The foundations of modern education. New York: Holt, Rinehart \& Winston.

WOLHUTER, C.C., STEYN, S.C. \& STEYN, H.J. 2003. Learning from southsouth comparison: the education systems of South Africa and Madagascar. South African Journal of Education, 23(1):29-35.

\section{Kernbegrippe:}

godsdiens

onderwys

onderwysstelsel

onderwysstelselbeplanning

sekularisme

\section{Key concepts:}

education

education system

education system planning

religion

secularism 
